\title{
Study of In-Vitro Antiviral Activity of Aminoglycosides on Foot and Mouth Disease Virus
}

\author{
Assem A Mohamed* \\ Department of FMD, Veterinary Serum and Vaccine Research Institute (VSVRI), Abassia, Cairo, Egypt \\ *Corresponding Author: Assem A Mohamed, Department of FMD, Veterinary Serum and Vaccine \\ Research Institute (VSVRI), Abassia, Cairo, Egypt.Email: svri@idsc.gov.eg
}

\begin{abstract}
Background: The aminoglycosides family of antibiotics are widely used as a prophylactic measure against bacterial contamination in animal vaccine production.
\end{abstract}

Objective: Screening the antiviral activity of some members of aminoglycosides on foot and mouth disease (FMD) viruses used in the preparation of FMD vaccine in veterinary serum and vaccine research institute (VSVRI) .

Method: This study was conducted by in-vitro assessment of cytopathic effect (CPE) and infectivity titers of FMD viruses on Baby hamster kidney (BHK) cells under different concentrations of Neomycin (200, 500 $\mathrm{mg} / \mathrm{L})$, kanamycin (200, $500 \mathrm{mg} / \mathrm{L})$, gentamycin (200, $500 \mathrm{mg} / \mathrm{L})$ and streptomycin (200, $500 \mathrm{mg} / \mathrm{L})$ as members of aminoglycosides using the inverted microscope. Positive (aminoglycosides-free) and negative (FMD viruses-free) were used.

Results: Our results show that aminoglycosides antibiotics could inhibit the cytopathic effect and reduce the infectivity titers of FMD viruses.

Conclusion: Finally we recommend the avoidance of routine inclusion of aminoglycosides antibiotics in tissue culture technique or treating FMD virus suspensions.

Keywords: FMD, VSVRI, CPE, BHK.

\section{INTRODUCTION}

Since the discovery of penicillin in 1928 many antibiotics including aminoglycosides, blactams, fluoroquinolones, and others have been applied clinically for the treatment of many growing number of multidrug-resistant strains of bacteria. Aminoglycosides in particular are being examined to find new compounds or derivatives that might overcome the existing resistant pathogens and prevent or slow the development of novel resistant pathogens.

Aminoglycosides were first established as antibiotics in the 1940s with the discovery of streptomycin and are still widely used worldwide. Aminoglycosides have enjoyed widespread application as chemotherapeutic agents in the treatments of many types of bacterial infections, including both Grampositive and Gram-negative pathogens (Davies and Wright 1997). The antibacterial mechanism of action of aminoglycosides has been well characterized, and it was discovered in the late

ARC Journal of Animal and Veterinary Sciences 1980s that aminoglycosides' molecular target is the $16 \mathrm{~S}$ rRNA subunit of the $30 \mathrm{~S}$ bacterial ribosome (Moazed and Noller 1987).

Although alternative modes of binding have been seen with various aminoglycoside derivatives (Kondo et al., 2007), the general interactions of aminoglycosides with three unpaired adenine residues in the decoding loop displaces non-complementary adenines and locks them into a so-called "flipped-out" orientation similar to that ob- served during mRNA decoding (Pfister et al., 2003, Vicens and Westhof 2003a, b, Shandrick et al., 2004, Ogle and Ramakrishnan 2005). Structural examples of these interactions from crystallographic or modeling studies are shown in, which depicts tobramycin, geneticin, amikacin, and paromomycin in complex with Asite oligonucleotides (Vicens and Westhof 2001, 2002, 2003a,b, Kondo et al., 2006). These interactions reduce the fidelity of normal 
translational processes by reducing the ability of the ribosome to discriminate between the proper mRNA-tRNA complexes, this leads to the accumulation of truncated or nonfunctional proteins in cells, and eventually to cell death. For a thorough structure-based analysis of the interactions of aminoglycosides with the decoding A-site see the recent review by (Francois et al 2005).

The structurally related aminoglycosides neomycin, paromomycin and gentamycin possess 4,5-substituted and 4,6-substituted 2deoxystreptamine cores. These compounds exert multiple effects on protein synthesis: they cause mRNA miscoding (Davies et al., 1965, 1966), inhibit mRNA and tRNA translocation (Cabanas et al., 1978 and Misumi et al., 1978, and inhibit ribosome recycling (Hirokawa, G. et al 2002).

Some aminoglycosides are considered to have antiviral activities. Hygromycin B was shown to inhibit replication of herpes simplex virus (Lacal et al., 1983), mouse hepatitis virus (Macintyre et al., 1991a,b), HIV type 1 (Gatti et al., 1998), influenza virus (Ghendon et al.,1981), and both encephalomyocarditis virus and Semliki forest virus (Lacal et al., 1980). Neomycin and recently developed neomycin analogs were also demonstrated to inhibit HIV replication and viral entry (Zapp et al., 1993; Herold \& Spear, 1994; Herold et al., 1994; Hung et al., 2002; Litovchick et al., 2000, 2001; Langeland et al., 1986, 1987).

BHK cells are derived from syrian baby hamster kidney (Mesocricetus auratus) (MacPherson and Stoker 1962). BHK cells are inherently anchorage dependent cells but also they are applied as suspension, too (Guo et al., 2015, Hernandez and Brown 2010, Reddy et al., 2016).

BHK cells are mainly used in animal products, particularly for FMD virus vaccine and rabies vaccine production (Vester et al., 2010, Park et al., 2010, Aunin 2010, Kallel et al. 2003, Rahman et al., 2007).

(Ingrid Kuhlmann 1996) mentioned that, In order to yield reproducable results, antibioticfree cell culture conditions are necessary. Germfree cell culture working conditions refer to those conditions which reduce the probability of contamination as much as possible, since absolute sterility is not possible. To achieve this, accurate techniques for sterile cell culture work is necessary.
(Lindl and Bauer (1989) observed that the prophylactic use of antibiotics in tissue culture techniques may cause workers to neglect sterile handling of cell cultures and therefore increase the possibility of development of resistant germs which lead to uncontrollable contaminations.

FMD is an acute contagious viral disease of cloven footed animals (Orsel et al., 2007). The causative agent is a single stranded positivesense RNA virus that belongs to the genus Aphthovirus in the family Picornaviridae. There are seven immunologically distinct serotypes of FMD virus, namely; O, A, C, SAT1, SAT2, SAT3 and Asia1 (Belsham, 1993).

FMD virion has a symmetric protein shell (or capsid) enclosing the genomic RNA. Genome RNA contains a positive single-strand chain approximately $8.3 \mathrm{~kb}$ long and encodes a single long open reading frame (ORF) of about $7 \mathrm{~kb}$ with two alternative initiation sites. The ORF is flanked by a long $5^{\prime}$-untranslated region (5'UTR) and a short $3^{\prime}-$ UTR, and ends with a genetic- ally encoded poly(A) tail (Grubman 1980). A genome-linked viral nonstructural protein (NSP), 3B (also known as $\mathrm{VPg}$ ) containing 23-24 amino acid (aa) residues, is covalently bound to its $5^{\prime}$ end, although this protein is rapidly re- leased into an infected cell and is deemed to play no part in translation initiation (Lin et al., 2009). The viral ORF can be translated into a polyprotein of about 250 $\mathrm{kDa}$, which is subsequently cleaved by two virus-encoded proteinases (leader (Lpro) and 3Cpro) to yield structural and NSPs (Robertson et al., 1985 and Mason et al., 2003).

In Egypt, The history of FMD virus goes back to 1950 (Mousa et al., 1974), when an outbreak caused by serotype SAT2 was reported. Between 1964 and 2005, only serotype $\mathrm{O}$ was reported in Egypt (Zahran 1960, and Farag et al., 2005), with the exception of 1972 when type A was introduced from Sub-Saharan Africa (Knowles et al., 2007). Series of outbreaks predominantly caused by serotype $\mathrm{O}$, and with a dramatic upsurge in FMD SAT 2 outbreaks during 2012 were reported (Ahmed et al., 2012, Shawkey et al., 2013). Serotypes O, A and SAT2 have been circulating in the country since 2012, and Serotype $O$ is considered the predominant serotype (FAO 2012).

The objective of this study was to Screen the antiviral activity of some members of aminoglycosides on FMD viruses used in the preparation of polyvalent FMD virus vaccine in VSVRI. 


\section{Materials AND MethodS}

\subsection{BHK Cells}

BHK cell line obtained from (FMD department, VSVRI, Egypt) was cultured in Minimal essential medium supplemented with a set of proteins including lactalbumin, treptose phosphate broth were added into this medium, sodium bicarbonate, and 10\% newborn calf serum supplied by Capricorn®.

\subsection{FMD Virus Strains}

Local FMDV strains (O /pan Asia2, A/ Iran 05, SAT2/ Egypt 2012 and SAT2/ Egypt 2018) were isolated and identified by Veterinary Serum and Vaccine Research Institute, Abbasia, Cairo. and confirmed by Pirbright (FMD-WRL), United Kingdom. FMDV were propagated in BHK21 cell line in roller bottles (Huang et al., 2011), Each virus had a infectivity titer of $10^{8}$ $50 \%$ tissue culture infective dose $/ \mathrm{ml}\left(10^{8}\right.$ TCID50/ml) as described by Reed and Muench (1938).

\subsection{Aminogylcoside Antibiotics}

Monitoring the inhibitory effect of neomycin $(200,500 \mathrm{mg} / \mathrm{L})$, kanamycin $(200,500 \mathrm{mg} / \mathrm{L})$,

Table1. The CPE (after 24 hrs at $37^{\circ} \mathrm{C}$ ) of FMD viruses on BHK cells treated by different concentrations of aminoglycosides antibiotics.

\begin{tabular}{|c|c|c|c|c|}
\hline & $\begin{array}{c}\text { O } / \text { pan Asia2 } \\
10^{8} \text { TCID50/ml }\end{array}$ & $\begin{array}{c}\text { A/ Iran 05 } \\
10^{8} \text { TCID50/ml }\end{array}$ & $\begin{array}{c}\text { SAT2/ Egypt 2012 } \\
10^{8} \text { TCID50/ml }\end{array}$ & $\begin{array}{c}\text { SAT2/ Egypt 2018 } \\
10^{8} \text { TCID50/ml }\end{array}$ \\
\hline $\begin{array}{c}\text { Neomycin } \\
(200 \mathrm{mg} / \mathrm{L})\end{array}$ & $\mathrm{NO} \mathrm{CPE}$ & $\mathrm{NO} \mathrm{CPE}$ & NO CPE & NO CPE \\
\hline $\begin{array}{c}\text { Neomycin } \\
(500 \mathrm{mg} / \mathrm{L})\end{array}$ & NO CPE & NO CPE & NO CPE & NO CPE \\
\hline $\begin{array}{c}\text { Kanamycin } \\
(200 \mathrm{mg} / \mathrm{L})\end{array}$ & $\mathrm{CPE}$ & $\mathrm{CPE}$ & $\mathrm{CPE}$ & $\mathrm{CPE}$ \\
\hline $\begin{array}{c}\text { Kanamycin } \\
(500 \mathrm{mg} / \mathrm{L})\end{array}$ & $\mathrm{CPE}$ & $\mathrm{CPE}$ & $\mathrm{CPE}$ & $\mathrm{CPE}$ \\
\hline $\begin{array}{c}\text { Gentamycin } \\
(200 \mathrm{mg} / \mathrm{L})\end{array}$ & $\mathrm{CPE}$ & $\mathrm{CPE}$ & $\mathrm{CPE}$ & $\mathrm{CPE}$ \\
\hline $\begin{array}{c}\text { Gentamycin } \\
(500 \mathrm{mg} / \mathrm{L})\end{array}$ & $\mathrm{CPE}$ & $\mathrm{CPE}$ & $\mathrm{CPE}$ & $\mathrm{CPE}$ \\
\hline $\begin{array}{c}\text { Streptomycin } \\
(200 \mathrm{mg} / \mathrm{L})\end{array}$ & $\mathrm{CPE}$ & $\mathrm{CPE}$ & $\mathrm{CPE}$ & $\mathrm{CPE}$ \\
\hline $\begin{array}{c}\text { Streptomycin } \\
(500 \mathrm{mg} / \mathrm{L})\end{array}$ & $\mathrm{CPE}$ & $\mathrm{CPE}$ & $\mathrm{CPE}$ & $\mathrm{CPE}$ \\
\hline $\begin{array}{c}\text { Negative control } \\
\text { (No virus) }\end{array}$ & $\mathrm{NO} \mathrm{CPE}$ & $\mathrm{NO} \mathrm{CPE}$ & NO CPE & NO CPE \\
\hline $\begin{array}{c}\text { Positive control } \\
\text { (No antibiotics) }\end{array}$ & $\mathrm{CPE}$ & $\mathrm{CPE}$ & $\mathrm{CPE}$ & $\mathrm{CPE}$ \\
\hline
\end{tabular}

So that, neomycin (at concentrations $\geq 200 \mathrm{mg} / \mathrm{L}$ ) has In-vitro antiviral action against FMD viruses.

These results were in agreement with Langeland et al., 1986, 1987, Zapp et al., 1993, Herold and Spear 1994, Herold et al., 1994, Litovchick et al., 2000, 2001, Hung et al., 2002 and Smita et al. 2018 who mentioned that the neomycin has mediated a potent antiviral effect. gentamycin $(200,500 \mathrm{mg} / \mathrm{L})$ and streptomycin $(200,500 \mathrm{mg} / \mathrm{L})$ on FMD viruses-induced CPE on BHK cells has been screened using the inverted microscope. Positive (aminoglycosidesfree) and negative (FMD viruses-free) were used.

\subsection{Inverted Microscope}

The CPE of FMD viruses on BHK cells was investigated using the inverted microscope.

\section{RESULTS AND DISCUSSION}

Aminoglycosides are one of the most important classes of antibiotics used in tissue culture technique that inhibit bacterial protein synthesis by targeting the ribosome (Magnet and Blanchard 2005). They are also excellent templates for antibiotic design because of their high binding affinity and properties that allow for broadspectrum antibacterial activity (Sutcliffe 2005).

The results of $24 \mathrm{hrs}-37^{\circ} \mathrm{C}$ anti-CPE effect of aminoglycosides on BHK cells infected by $10^{8}$ TCID $50 / \mathrm{ml}$ of FMD viruses revealed that neomycin (at concentrations $\geq 200 \mathrm{mg} / \mathrm{L}$ ) inhibits the CPE of FMD viruses on BHK cells as shown in table (1).
The effect of aminoglycosides on The $24 \mathrm{hrs}-37^{\circ} \mathrm{C}$ infectivity titers expressed as TCID50/ml of FMD viruses treated by different concentrations of aminoglycosides antibiotics starting as $10^{8}$ TCID50/ml revealed that all the aminoglycosides 
in this study affect infectivity titers (expressed as $500 \mathrm{mg} / \mathrm{L})$ as shown in table (2).

TCID50) except streptomycin (at concentrations $\leq$

Table2. The infectivity titers expressed as TCID50/ml (after $24 \mathrm{hrs}$ at $37^{\circ} \mathrm{C}$ ) of FMD viruses treated by different concentrations of aminoglycosides antibiotics starting as $10^{8} \mathrm{TCID} 50 / \mathrm{ml}$.

\begin{tabular}{|c|c|c|c|c|}
\hline & $\begin{array}{c}\text { O/pan Asia2 } \\
10^{8} \text { TCID50/ml }\end{array}$ & $\begin{array}{c}\text { A/ Iran 05 } \\
10^{8} \text { TCID50/ml } \\
\end{array}$ & $\begin{array}{c}\text { SAT2/ Egypt } 2012 \\
10^{8} \text { TCID50/ml } \\
\end{array}$ & $\begin{array}{c}\text { SAT2/ Egypt } 2018 \\
10^{8} \text { TCID50/ml } \\
\end{array}$ \\
\hline $\begin{array}{l}\text { Neomycin } \\
(200 \mathrm{mg} / \mathrm{L})\end{array}$ & NO CPE & NO CPE & NO CPE & NO CPE \\
\hline $\begin{array}{l}\text { Neomycin } \\
(500 \mathrm{mg} / \mathrm{L})\end{array}$ & NO CPE & NO CPE & NO CPE & NO CPE \\
\hline $\begin{array}{l}\text { Kanamycin } \\
(200 \mathrm{mg} / \mathrm{L})\end{array}$ & $10^{6}$ TCID50/ml & $10^{6} \mathrm{TCID50} / \mathrm{ml}$ & $10^{6} \mathrm{TCID50} / \mathrm{ml}$ & $10^{6} \mathrm{TCID50} / \mathrm{ml}$ \\
\hline $\begin{array}{l}\text { Kanamycin } \\
(500 \mathrm{mg} / \mathrm{L})\end{array}$ & $10^{6}$ TCID50/ml & $10^{6} \mathrm{TCID50} / \mathrm{ml}$ & $10^{6}$ TCID50/ml & $10^{6} \mathrm{TCID50} / \mathrm{ml}$ \\
\hline $\begin{array}{c}\text { Gentamycin } \\
(200 \mathrm{mg} / \mathrm{L})\end{array}$ & $10^{7}$ TCID50/ml & $10^{6} \mathrm{TCID50} / \mathrm{ml}$ & $10^{6}$ TCID50/ml & $10^{6} \mathrm{TCID50} / \mathrm{ml}$ \\
\hline $\begin{array}{c}\text { Gentamycin } \\
(500 \mathrm{mg} / \mathrm{L})\end{array}$ & $10^{6}$ TCID50/ml & $10^{5} \mathrm{TCID50} / \mathrm{ml}$ & $10^{5}$ TCID50/ml & $10^{5}$ TCID50/ml \\
\hline $\begin{array}{l}\text { Streptomycin } \\
(200 \mathrm{mg} / \mathrm{L})\end{array}$ & $10^{8}$ TCID50/ml & $10^{8} \mathrm{TCID50} / \mathrm{ml}$ & $10^{8}$ TCID50/ml & $10^{8} \mathrm{TCID50} / \mathrm{ml}$ \\
\hline $\begin{array}{c}\text { Streptomycin } \\
(500 \mathrm{mg} / \mathrm{L})\end{array}$ & $10^{8}$ TCID50/ml & $10^{8}$ TCID50/ml & $10^{8}$ TCID50/ml & $10^{8} \mathrm{TCID50} / \mathrm{ml}$ \\
\hline $\begin{array}{l}\text { Negative control } \\
\text { (No virus) }\end{array}$ & NO CPE & NO CPE & NO CPE & NO CPE \\
\hline $\begin{array}{l}\text { Positive control } \\
\text { (No antibiotics) }\end{array}$ & $10^{8}$ TCID50/ml & $10^{8}$ TCID50/ml & $10^{8}$ TCID50/ml & $10^{8}$ TCID50/ml \\
\hline
\end{tabular}

These results were in agreement with Lacal et al., 1980,1983, Macintyre et al., 1991a,b, Ghendon et al., 1981 and Gatti et al., 1998 who mentioned that the neomycin inhibit RND viruses replication and viral entry.

In this work we studied the In-vitro effects of Aminoglycosides antibiotics on FMD viruses used in preparation of polyvalent FMD vaccine in VSVRI in Egypt. The effects concerned in this study we CPE formation on BHK cells and infectivity titers.

The antibacterial mechanism of action of aminoglycosides has been well characterized, and it was discovered in the late 1980s that aminoglycosides molecular target is the $16 \mathrm{~S}$ rRNA subunit of the $30 \mathrm{~S}$ bacterial ribosome Moazed and Noller 1987.

The results revealed that aminoglycosides antibiotics have In-vitro dose and memberdependant antiviral activity against FMD viruses. Theses results are supported by Lai $\boldsymbol{e t}$ al., 2004; Konno et al., 2004; Borovinskaya et al., 2007a,b, Cabanas et al., 1978; Eustice and Wilhelm, 1984 who mentioned that the natural and synthesized aminoglycoside-based antibiotics inhibit viral translation, resulting in a decrease of viral RNA synthesis and can be a potent tool to explore and develop new specific antiviral drugs against pathogenic RNA viruses.
Our results are also confirmed by Ingrid Kuhlmann (1996) who mentioned that the prophylactic use of antibiotics risks neglect of sterile technique. Moreover, antibiotics may have side effects on the cells. Consequently, the prophylactic use of antibiotics may effect the results of experiments.

Finally we recommend the avoidance of using aminoglycosides antibiotics (except streptomycin at concentration $\leq 500 \mathrm{mg} / \mathrm{L}$ ) in treating FMD virus suspensions or isolation of FMD viruses as it may weaken or even inhibit these RNA viruses. Also the routine inclusion of aminoglycosides antibiotics in tissue culture technique is contraindicated.

\section{REFERENCES}

[1] Ahmed, H., Salem, S., Habashi, A., Arafa, A., Aggour, M., Salem, G., Gaber, A., Selem, O., Abdelkader, S. \& Knowles, N. (2012): Emergence of Foot-and-Mouth Disease Virus SAT 2 in Egypt During 2012. Transboundary and emerging diseases,59:476-481.

[2] Aunin, J.G., (2010): Viral vaccine production in cell culture. In: Flickinger M.C. (ed) Encyclopedia of industrial biotechnology: bioprocess, bioseparation, and cell technology. Wiley, New York, 2010, pp 1-35.

[3] Belsham, G.J. (1993): Distinctive features of FMDV, a member of the Picorna virus family, aspects of virus protein synthesis, protein processing and structure. Progress in 
Biophysics and Molecular Biology 60: 241260.

[4] Borovinskaya M.A., Pai R.D., Zhang W., Schuwirth B.S., Holton J.M., Hirokawa G., Kaji H., Kaji A., Cate J.H. (2007): Structural basis for aminoglycoside inhibition of bacterial ribosome recycling. Nat Struct Mol Biol 2007a;14:727-732. [PubMed: 17660832]

[5] Cabanas M.J., Vázquez D., Modolell J. (1978): Inhibition of ribosomal translocation by aminoglycoside antibiotics. Biochem Biophys Res Commun 1978;83:991-997. [PubMed: 361042]

[6] Davies, J., Gorini, L., Davies, B.D. (1965): Misreading of RNA codewords induced by aminoglycoside antibiotics. Mol. Pharmacol. 1, 93-106 (1965).

[7] Davies, J., Jones, D..S., Khorana, H.G. (1966): A further study of misreading of codons induced by streptomycin and neomycin using ribopolynucleotides containing two nucleotides in alternating sequence as templates. J. Mol. Biol. 18, 48-57 (1966).

[8] Davies, J. and Wright,G. D., (1997):Trends Microbiol. 1997, 5, 234.

[9] Eustice D.C. and Wilhelm J.M. (1984): Mechanisms of action of aminoglycoside antibiotics in eucaryotic protein synthesis. Antimicrob Agents Chemother 1984;26:53 60. [PubMed: 6433789]

[10] FAO (2012): http://www.wrlfmd.org/fmd_ genotyping/africa/egy.htm.

[11] Farag, M.A., Aggour, M. A. and Daoud, A.M. (2005): ELISA as a rapid method for detecting the correlation between the field isolates of FMD and the current used vaccine strain in Egypt. Vet. Med. J. Giza, Vol. 53 no. 4: $949-955$.

[12] Francois, B., Russell, R. J., Murray, J. B., Aboul-ela, F., Masquida, B., Vicens, Q., Westhof, E. (2005): Nucleic Acids Res. 2005, 33, 5677.

[13] Gatti P.J., Choi B., Haislip A.M., Fermin C.D., Garry R.F.(1998): Inhibition of HIV type 1 production by hygromycin B. AIDS Res Hum Retroviruses 1998;14:885-892. [PubMed: 9671217]

[14] Ghendon, YuZ, Klimov, A.I. (1981): Effects of edeine, hygromycin B and alpha-Sarcin on influenza virus reproduction. Acta Virol 1981;25:129-137. [PubMed: 6115560]

[15] Grubman M.J. (1980): The 5' end of foot-andmouth disease virion RNA contains a protein covalently linked to the nucleotide pUp. Arch Virol. 1980;63:311-5.

[16] Guo H, Jin Y, Shi-Chong H, Shi-Qi Sun. (2015): Quantitative Proteomic Analysis of BHK 21Cells Infected with Foot-and-Mouth
Disease Virus Serotype Asia 1. PLOS ONE, 2015.

[17] Hernandez, R., Brown, D.T., (2010): Growth and maintenance of baby hamster kidney (BHK) cells. Curr Protoc Microbiol. Chapter 4: Appendix 4H, 2010.

[18] Hirokawa, G. et al. (2002): Post-termination complex disassembly by ribosome recycling factor, a functional tRNA mimic. EMBO J. 21, 2272-2281 (2002).

[19] Herold B.C., Spear P.G. (1994): Neomycin inhibits glycoprotein $\mathrm{C}$ ( $\mathrm{gC}$ )-dependent binding of herpes simplex virus type 1 to cells and also inhibits postbinding events in entry. Virology 1994;203:166-171. [PubMed: 8030274]

[20] Herold B.C, Visalli R.J., Susmarski N., Brandt C.R., Spear P.G. (1994): Glycoprotein $\mathrm{C}$-independent binding of herpes simplex virus to cells requires cell surface heparan sulphate and glycoprotein B. J. Gen. Viro 11994;75: 12 11-1222. [PubMed: 8207388]

[21] Huang Xuan, Li.,Y., Fang, H., Zheng,C. (2011): Establishment of persistent infection of foot and mouth disease virus in BHK-21 cells. Virology Journal, 8:169.

[22] Hung S.L., Wang Y.H., Chen H.W., Lee P.L., Chen Y.T. (2002): Analysis of herpes simplex virus entering into cells of oral origin. Virus Res 2002;86:59-69. [PubMed: 1207683 0]

[23] Ingrid Kuhlmann (1996) The prophylactic use of antibiotics in cell culture. Cytotechnology 19: 95-105, 1996. $95 @ 1996$ Kluwer Academic Publishers. Printed in the Netherlands.

[24] Kallel, H., Rourou, S., Majou, S., Loukil, H., (2003): Appl. Microbiol. Biotechnol., 61, 441 (2003).

[25] Knowles, N. J., Wadsworth, J., Reid, S. M., Swabey, K. G., EL-Kholy, A. A., ELRahman, A. O. A., Ssoliman, H. M., Ebert, K., Ferris, N. P. \& Hutchings, G. H. (2007): Foot-and-mouth disease virus serotype $\mathrm{A}$ in Egypt. Emerging infectious diseases, 13:1593.

[26] Kondo, J., Francois, B., Russell, R. J., Murray, J. B., Westhof, E. (2006): Biochimie 2006, 88, 1027.

[27] Kondo, J., Pachamuthu, K., Francois, B., Szychowski, J., Hanessian, S., Westhof, E., (2007): ChemMedChem 2007, 2, 1631.

[28] Konno T., Takahashi T., Kurita D., Muto A., Himeno H. (2004): A minimum structure of aminoglycosides that causes an initiation shift of trans-translation. Nucleic Acids Res 2004;32:4119-4126. [PubMed: 15295039]

[29] Lacal J.C., Carrasco L. (1983): Antiviral effects of hygromycin B, a translation inhibitor nonpermeant to uninfected cells. Antimicrob Agents Chemother 1983;24:273-275. [PubMed: 6314888] 
[30] Lacal J.C., Vázquez D., Fernandez-Sousa J.M., Carrasco L.(1980): Antibiotics that specifically block translation in virus-infected cells. J Antibiot (Tokyo) 1980;33:441-446. [PubMed: 6251018]

[31] Lai C.H., Chun H.H., Nahas S.A., Mitui M., Gamo K.M., Du L., Gatti R.A. (2004): Correction of ATM gene function by aminoglycoside-induced read-through of premature termination codons. Proc Natl Acad Sci U S A 2004;101:15676-15681. [PubMed: 15498871]

[32] Langeland N., Haarr L., Holmsen H. (1986): Evidence that neomycin inhibits HSV 1 infection of BHK cells. Biochem Biophys Res Commun 1986;141:198-203. [PubMed: 3026 374]

[33] Langeland N., Holmsen H., Lillehaug J.R., Haarr L. (1987): Evidence that neomycin inhibits binding of herpes simplex virus type 1 to the cellular receptor. J Virol 1987;61:33883393. [PubMed: 2822948]

[34] Lin J.Y., Chen T.C., Weng K.F., Chang S.C., Chen L.L., Shih S.R. (2009): Viral and host proteins involved in picornavirus life cycle. $\mathrm{J}$ Biomed Sci. 2009; 16:103.

[35] Lindl $T$ and Bauer J (1989) Zell- und Gewebekultur. 2. Aufl., Gustav Fischer Verlag, Stuttgart/New York.

[36] Litovchick A., Evdokimov A.G., Lapidot A. (2000): Aminoglycoside-arginine conjugates that bind TAR RNA: synthesis, characterization, and antiviral activity. Biochemistry 2000;39:28382852. [PubMed: 10715103]

[37] Litovchick A., Lapidot A., Eisenstein M., Kalinkovich A., Borkow G. (2001): Neomycin B-arginine conjugate, a novel HIV-1 Tat antagonist: synthesis and anti-HIV activities. Biochemistry 2001;40:15612-15623. [PubMed: 11747436]

[38] Macintyre G., Curry B., Wong F., Anderson R.(1991a): Hygromycin B therapy of a murine coronaviral hepatitis. Antimicrob Agents Chemother 1991a;35:2125-2127. [PubMed: 1662025]

[39] Macintyre G., Woods D.E., Anderson R. (1991b): Hygromycin B inhibits synthesis of murine coronavirus RNA. Antimicrob Agents Chemother 1991b;35:2630-2633. [PubMed: 1667257]

[40] MacPherson, I., Stoker, M.,(1962): Virology, 16, 147 (1962).

[41] Magnet, S. and Blanchard, J.S. (2005): Molecular insights into aminoglycoside action and resistance. Chem. Rev. 105, 477-498 (2005).

[42] Mason P.W., Grubman M.J., Baxt B. (2003): Molecular basis of pathogenesis of FMDV.Virus Res. 2003;91:9-32.

ARC Journal of Animal and Veterinary Sciences
[43] Misumi, M., Nishimura, T., Komai, T., Tanaka, N. (1978): Interaction of kanamycin and related antibiotics with the large subunit of ribosomes and the inhibition of transloca- tion. Biochem. Biophys. Res. Commun. 84, 358-365 (1978).

[44] Moazed, D and Noller, H. F., (1987): Nature 1987, 327, 389.

[45] Mousa,A.A.;Boulaus,S.M.;Elsayed;F.S.and Bohm,H.O.(1974): Typing and subtyping of a strain of FMD isolated from sharquia province, 1970.J.egypt,assuit Veterinary Medicine, Vol.(34) No.(3-4) : (413-419).

[46] Ogle, J. M. and Ramakrishnan, V. (2005): Annu. Rev. Biochem. 2005, 74, 129.

[47] Orsel,K.;deJong,M.C.;Bouma,A.;Stegeman, J.A.andDekker,A.(2007): Foot and mouth disease virus transmission among vaccinated pigs after exposure to virus shedding pigs. Vaccine 2 21;25(34):6381-91.

[48] Park J.H., Park H.H., Park T.H.,(2010): Korean J Chem. Eng., 27, 1042 (2010).

[49] Pfister, P., Hobbie, S., Vicens,Q., Bottger, E. C., Westhof, E. (2003):ChemBioChem 2003, 4, 1078 .

[50] Rahman, S., Rabbani, M., Sahidullah, Muhammad,K., Iqball,Z.,(2007): Int. J. Agri. Biol., 9, 821 (2007).

[51] Reddy, B.P., Reddy, B.P., Rayulu, D.J., (2016): Int. J. Apll. Biol. Pharm.Technol., 7, 122 (2016).

[52] Reed L.J. and Muench H A. (1938): simple method of estimating fifty percent endpoints. Am. J.Hyg. 1938; 27(3): 493-497.

[53] Robertson B.H., Grubman M.J., Weddell G.N., Moore D.M., Welsh J.D., Fischer T., Dowbenko D.J., Yansura D.G., Small B., Kleid D.G. (1985): Nucleotide and amino acid sequence coding for polypeptides of foot-andmouth disease virus type A12. J Virol. 1985; $54: 651-60$

[54] Shandrick,S., Zhao, Q. Han, Q., Ayida, B. K., Takahashi, M., Winters,G. C., Simonsen, K. B., Vourloumis, D., Hermann, T. (2004): Angew. Chem. 2004, 116, 3239; Angew. Chem. Int. Ed. 2004, 43, 3177.

[55] Shawky M., Abd El-Aty M., Hiam. M. Fakry, Hind M. Daoud, Ehab El-Sayed I., Wael Mossad G., Sonia A. Rizk, Abu-EInaga H., Mohamed A. A., Abd Elkreem A. and Farouk E. M. (2013): Isolation and Molecular Characterization of Foot and Mouth Disease SAT2 Virus during Outbreak 2012 in Egypt. $J$. Vet. Adv. 2013, 3(2): 60-68. 
[56] Smita Gopinath, Myoungjoo V. Kim, Tasfia Rakib, Patrick W. Wong, Michael van Zandt, Natasha A. Barry, Tsuneyasu Kaisho, Andrew L. Goodman and Akiko Iwasaki, (2018): Topical application of aminoglycoside antibiotics.natural microbiology-vol 3, may 2018, 611-621.

[57] Sutcliffe, J.A. (2005): Improving on nature: antibiotics that target the ribosome. Curr. Opin. Microbiol. 8, 534-542 (2005).

[58] Vester, D., Rapp, E., Kluge, S., Genzel, Y., Reichl, U., (2010): J Proteomics, 73, 1656 (2010).

[59] Vicens,Q., Westhof, E.(2001):Structure 2001, $9,647$.
[60] Vicens,Q., Westhof, E. (2002): Chem. Biol. 2002, 9, 747.

[61] Vicens,Q., Westhof, E. (2003a): J. Mol. Biol. 2003, 326, 1175.

[62] Vicens, Q. and Westhof, E. (2003b):Biopolymers 2003, 70, 42.

[63] Zahran, G.E.D. (1960): Foot and mouth disease in southern region of URA.Bull. Off. Int. Epiz., 13: 390- 393.

[64] Zapp M.L., Stern S., Green M.R. (1993): Small molecules that selectively block RNA binding of HIV-1 Rev protein inhibit Rev function and viral production. Cell 1993; 74:969-978. [PubMed: 8402886]

Citation: Assem A Mohamed. Study of In-Vitro Antiviral Activity of Aminoglycosides on Foot and Mouth Disease Virus. ARC Journal of Animal and Veterinary Sciences. 2019; 5(1):24-30. doi: dx.doi.org/10.20431/2455-2518.0501004.

Copyright: (c) 2019 Authors. This is an open-access article distributed under the terms of the Creative Commons Attribution License, which permits unrestricted use, distribution, and reproduction in any medium, provided the original author and source are credited. 